\title{
Determination of Gibberellic Acid by Sequential Injection Analysis Using a Potentiometric Detector Based on Mn(III)-Porphyrin with Improved Characteristics
}

\author{
Emília M. G. Santos ${ }^{a}$, Cristina M. C. M. Couto ${ }^{*, a, b}$, Alberto N. Araújo ${ }^{a}$, \\ M. Conceição B. S. M. Montenegro ${ }^{a}$ and Boaventura F. Reis ${ }^{c}$ \\ ${ }^{a}$ REQUIMTE/Department of Physical Chemistry, Faculty of Pharmacy, Rua Aníbal Cunha, 164, 4050-047, Porto, Portugal \\ ${ }^{b}$ ISCS- Norte- Rua Central da Gandra-1317, GRD Paredes, Portugal \\ ${ }^{c}$ Centro de Energia Nuclear para a Agricultura, Universidade de São Paulo, Avenida Centenário, 303, CP 96, \\ 13400-970 Piracicaba - SP, Brazil
}

\begin{abstract}
Descreve-se a determinação de ácido giberélico em promotores de crescimento usados na agricultura, por análise de injecção sequencial e detecção potentiométrica. Os detectores potentiométricos com características melhoradas usam uma membrana de PVC preparada com $\mathrm{Mn}(\mathrm{III})$ tetrafenilporfirina- $\mathrm{Cl}$ ([( $\mathrm{Mn}(\mathrm{TPP}) \mathrm{Cl}])$. Formularam-se diferentes membranas comparandose aditivos iónicos com o objectivo de se seleccionar as unidades com as melhores características de declive, tempo de resposta, reprodutibilidade e selectividade. Para fins analíticos foi seleccionada uma membrana com $6 \%$ de [(Mn(TPP)Cl], 27\% de PVC, 66\% de dibutilftalato (DBP), como solvente mediador, e $1 \%$ de tetrafenilborato de sódio, como aditivo aniónico. Quando inserido num sistema SIA o eléctrodo tubular apresentava um intervalo de linearidade de $5 \times 10^{-4} \mathrm{~mol} \mathrm{~L}^{-1}$ a $8 \times 10^{-3}$ mol L ${ }^{-1}$, declive de $-64,5 \pm 1,6 \mathrm{mV} /$ dec e melhores coeficientes de selectividade potenciométrica (log $\mathrm{K}^{\mathrm{pot}}$ ) do que os obtidos com eléctrodos convencionais. Na análise de amostras comercializadas em Portugal obtiveram-se desvios padrão de 0,01 e $0,4(n=4)$ e um ritmo de amostragem de 30 amostras/hora.
\end{abstract}

This work describes the determination of gibberellic acid in growth promoters formulations used in agriculture by sequential injection analysis and potentiometric detection. The potentiometric detectors with improved characteristics used a PVC membrane prepared with $\mathrm{Mn}$ (III)tetraphenylporphyrin-Cl as electroactive specie. Different membranes formulated with several ionic additives were compared in order to select the most suitable one concerning slope, response time, reproducibility and selectivity. A membrane containing $6 \mathrm{wt} \%$ of manganese tetraphenylporphyrin- $\mathrm{Cl}[(\mathrm{Mn}(\mathrm{TPP}) \mathrm{Cl}], 27 \mathrm{wt} \%$ of PVC, $66 \mathrm{wt} \%$ of dibutylphthalate (DBP), as mediator solvent, and $1 \mathrm{wt} \%$ of sodium tetraphenylborate, as anionic additive, was chosen for analytical applications. When coupled to a SIA system the tubular electrode presented a linear range between $5 \times 10^{-4} \mathrm{~mol} \mathrm{~L}^{-1}$ and $8 \times 10^{-3} \mathrm{~mol} \mathrm{~L}^{-1}$, a slope of $-64.5 \pm 1.6 \mathrm{mV} / \mathrm{dec}$ and lower potentiometric selectivity coefficients $\left(\log \mathrm{K}^{\mathrm{pot}}\right)$ than those obtained with the conventional electrodes. Standard deviation of 0.01 and $0.4(n=4)$ and a sampling rate of 30 samples/hour were obtained in the analysis of real samples.

Keywords: gibberellic acid, ion selective tubular electrode, SIA, metalloporphyrins, agricultural growth promoters

\section{Introduction}

Successful agriculture activities are nowadays dependent on careful planning based on the knowledge of local climate, soil characteristics and controlled growth by extensive use of pesticides, fertilizers and growth

* e-mail: couto_cristina@ @otmail.com chemical promoters. In this context, gibberellic acid (2,4 $\alpha, 7$-trihydroxy-1-methyl-8-methylenegib-3-ene-1,10dicarboxylic acid 1,4 $\alpha$-lactone) (Figure 1a) and related gibberellins are often used in cultures of growing crops (field crops, small fruits, vines and tree fruits), ornamental and shade trees, and ornamental plants, shrubs and vines, once it favours seed germination and stem elongation due to its characteristics as terpenoid hormone. Its low 


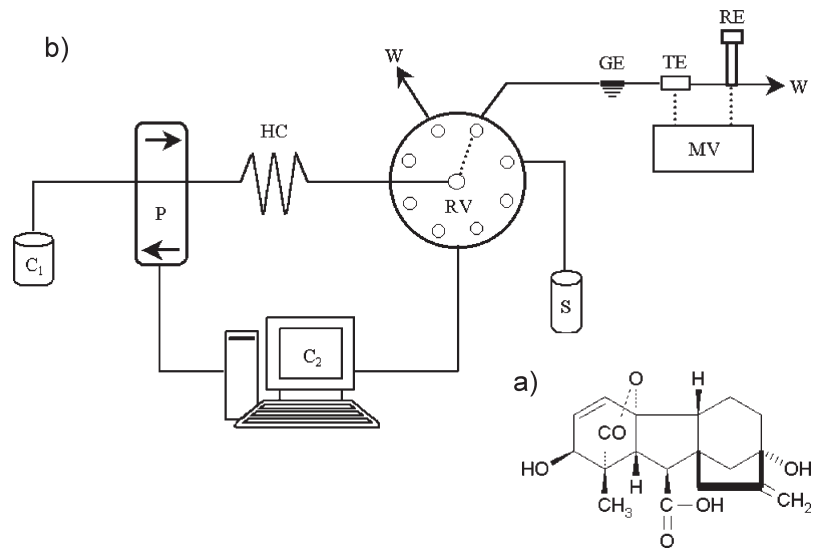

Figure 1. Gibberellic acid chemical structure (a) and sequential injection system (b). Peristaltic pump (P); rotatory valve (RV); sample or standard solutions (S); holding coil (HC); waste (W); grounding electrode (GE); gibberellate selective electrode (TE); reference electrode $(\mathrm{RE})$; carrier solution $\left(\mathrm{C}_{1}\right)$; computer $\left(\mathrm{C}_{2}\right)$; decimillivoltimeter (MV).

mammalian and environmental toxicity and dose-related effects justifies its extensive use and impels for the proposal of adequate and simple chemical control procedures. Until now laborious and costly methods have been proposed based on HPLC with spectrophotometric detection, ${ }^{1-3}$ thin layer chromatography with fluorimetric detection, ${ }^{4}$ synchronous scanning derivative spectrofluorimetry ${ }^{5}$ and immunoassays. ${ }^{6}$ Aiming the study of potentiometric selective electrodes based on the use of metalloporphyrins as selective ionophores, our group has proposed a potentiometric unit for the determination of gibberellate. ${ }^{7}$ The interest in the use of metalloporphyrins as ionophores is related to the fact that these compounds exhibit potentiometric anion selectivity sequences markedly different from the Hofmeister pattern (based on anion free energy of hydration) ${ }^{8}$ always found for membranes doped with lipophilic anion-exchangers. ${ }^{9}$ Their anion selectivity is both correlated with the lipophilic porphyrin structure and the specific metal-ligand interactions. ${ }^{10}$ Such selectivity can be optimised via the addition of appropriate lipophilic cationic or anionic site additives to the membrane. ${ }^{11}$ The use of porphyrins with different metal centres can also lead to sensors with distinctly different preferences for given ions. $\mathrm{Mn}$ (III)metalloporphyrins have been successfully used in the preparation of electrodes for the determination of other organic carboxylates, such as salicylate. ${ }^{12}$ In a previous work ${ }^{7} \mathrm{Mn}(\mathrm{III}) \mathrm{TPP}-\mathrm{Cl} .7 \mathrm{H}_{2} \mathrm{O}$ was used as ionophore for gibberellate ion selective electrodes construction and some drawbacks such as fair reproducibility and stability and insufficient selectivity were noticed being the application in direct analysis limited to the simpler formulations.

In this work, potentiometric gibberellate selective membranes formulated with $\mathrm{Mn}(\mathrm{III}) \mathrm{TPP}-\mathrm{Cl} \cdot \mathrm{H}_{2} \mathrm{O}$ and different additives were developed and evaluated in order to select a membrane for preparing tubular detectors for automated determination procedures of that specie in real samples. Besides improvement of above mentioned electrodes characteristics, continuous flow techniques such as sequential-injection analysis used in this work enables an easier manipulation of samples and reagent solutions, high sampling rates and cleaner determination procedures.

\section{Experimental}

\section{Reagents and solutions}

Deionised water (conductivity less than $0.1 \mu \mathrm{S} \mathrm{cm}^{-1}$ ) was used in preparation of all solutions. Analytical grade chemicals were used without any additional chemical purification. Reagents used in the preparation of sensor membranes were manganese (III) tetraphenylporphyrinchloride (Mn(TPP)-Cl. $\mathrm{H}_{2} \mathrm{O}$ ) (Aldrich), dibutylphthalate (DBP) (Riedel de-Haen), poly(vinyl chloride) (PVC) (Fluka), tetra-n-octylammonium bromide (Fluka), sodium tetraphenylborate (Aldrich), $p$-tert-octylphenol (Fluka) and tetrahydrofuran (Riedel de-Haen).

A buffer solution containing $0.01 \mathrm{~mol} \mathrm{~L}^{-1}$ of 2-morpholinoethanesulphonic acid (MES) (Fluka) ${ }^{13}$ was used as background solution in the evaluation of electrodes in batch conditions and as carrier solution in SIA system, to accomplish $\mathrm{pH}$ and ionic strength adjustment of the injected solutions. In this way the influence of $\mathrm{OH}$ is minimized whatever the composition of the electrode membrane under evaluation. A stock standard solution of gibberellate $\left(0.01 \mathrm{~mol} \mathrm{~L}^{-1}\right)$ was obtained by dilution of gibberellic acid (Fluka) in buffer solution.

In the real sample analysis by the HPLC method proposed by Martinez et al., ${ }^{2}$ the mobile phase was made up of a degasified mixture of $300.0 \mathrm{~mL}$ of methanol and $700.0 \mathrm{~mL}$ of a $10^{-2} \mathrm{~mol} \mathrm{~L}^{-1}$ phosphoric acid solution whose $\mathrm{pH}$ was previously adjusted to 3.0 with $0.1 \mathrm{~mol} \mathrm{~L}^{-1} \mathrm{KOH}$. This eluent was also used for the preparation of a $1 \mathrm{mg} \mathrm{mL}^{-}$ ${ }^{1}$ gibberellic acid standard solution and as solvent of the remaining less-concentrated solutions.

In Portugal, Gibberellic acid is commercialised under two types of formulation, one of them as liquid (Ácido Giberélico 1.6\%-Agar-Narangib) and the other as effervescent tablets (Berelex). Different procedures were taken on the preparation of samples for the potentiometric analysis. For Ácido Giberélico 1.6\%, an initial volume of product equal to $5.0 \mathrm{~mL}$ was evaporated in a rotaryevaporator glass flask to eliminate the solvent (propanol) and the residue was recovered with the MES buffer up to a 
volume of $200.0 \mathrm{~mL}$, in order to obtain a solution of gibberellate anion of about $1 \times 10^{-3} \mathrm{~mol} \mathrm{~L}^{-1}$. For Berelex, an amount of $0.25 \mathrm{~g}$ of product was weighed after tablets powdering, and a volume of about $30.0 \mathrm{~mL}$ of absolute ethanol was added to extract gibberellic acid in an ultrasonic bath for 15 minutes. This solution was filtrated and the solvent was evaporated, being the residue made up to a volume of $50.0 \mathrm{~mL}$ with the buffer MES, resulting in a sample whose concentration was approximately $1.5 \times 10^{-3} \mathrm{~mol} \mathrm{~L}^{-1}$.

For the independent method based on the HPLC technique different sample preparations were also adopted. In the first case propanol content of $2.0 \mathrm{~mL}$ of sample was first evaporated. The residue obtained was made up to a volume of $50.0 \mathrm{~mL}$ with eluent solution in order to obtain a gibberellic acid concentration of about $0.64 \mathrm{mg} \mathrm{mL}^{-1}$. In the case of tablets, a quantity of powder equivalent to $0.25 \mathrm{~g}$ was weighed. The gibberellic acid was extracted with $30.0 \mathrm{~mL}$ of absolute ethanol in an ultrasonic bath, during $15 \mathrm{~min}$. After filtration and evaporation of solvent the residue was equally made up with a solution of eluent to a final volume of $50.0 \mathrm{~mL}$. The concentration of gibberellic acid was approximately equal to $0.5 \mathrm{mg} \mathrm{mL}^{-1}$.

\section{Apparatus and electrodes}

The SIA system developed (Figure 1) comprised of a multiposition 8-port fluid selecting valve (RV) from Valco Instruments (Houston, USA), model Cheminert ${ }^{\mathrm{TM}} \mathrm{C} 15$ 3118E, a 4-channel Gilson Minipuls 3 peristaltic pump (PP) (Villiers-le-Bel, France) and a Crison micro pH 2002 decimillivoltimeter. The SIA manifold involved PTFE connection tubing $(0.8 \mathrm{~mm}$ id). The holding-coil (HC) between the peristaltic pump and the rotary valve was 400 $\mathrm{cm}$ long and was coiled over a plastic net. Some home made devices such as joint pieces, grounding electrode, supports for tubular and reference electrodes as described elsewhere ${ }^{14}$ were also used.

The potentiometric detection unit was connected to port 8 of RV with a $80 \mathrm{~cm}$ length tube and comprised a tubular gibberellate-selective electrode constructed following the previously described methodology ${ }^{15}$ coupled to a double junction Orion reference electrode ( $\mathrm{AgCl} / \mathrm{Ag})$, model 90-02-00, with a $0.01 \mathrm{~mol} \mathrm{~L}^{-1} \mathrm{MES}$ solution in the external compartment. The system was computer controlled through an Advantech PCL-711B interface card by running software written in Quick Basic programming language. For $\mathrm{pH}$ measurements a combined glass electrode Phillips GAH was used.

A Merck Hitachi chromatographic system composed by a Rheodyne model 7100 pump, Rheodyne $7725 \mathrm{i}$ injector (loop de $20 \mu \mathrm{L})$ and a RP $18(250 \mathrm{~mm} \times 4 \mathrm{~mm})$ chromatographic column packed with $5 \mu \mathrm{m}$ Lichrosorb particles was used. As detector, a diode array system (model 7455) was used while the data was processed by incorporated software (model D7000).

\section{Membrane preparation and electrode construction}

Four different types of potentiometric membranes for electrode construction were prepared. The sensor solutions used in the electrodes membrane preparation were obtained by dissolving the ionophore ( $\left.\mathrm{Mn}(\mathrm{TPP})-\mathrm{Cl}_{2} \mathrm{H}_{2} \mathrm{O}\right)$ in dibutylphthalate as plasticizer solvent and by adding in some of them different additives. A solution of PVC prepared in tetrahydrofuran was mixed with the sensor solutions in order to get physical immobilization after tetrahydrofuran evaporation. Taking into account that the charge number of the primary and interfering ions and stoichiometry of their complexes with the ionophore not only influences the optimum concentration of ionic sites but also determines the charge sign of the ionic sites that give the highest selectivities ${ }^{11}$ different types of lipophilic compounds, namely $p$-tert-octylphenol (membrane type 1) as no charged additive, sodium tetraphenylborate as anionic additive (membrane type 2) and tetra-noctylammonium bromide as cationic additive (membrane type 3) were used. Conventionally shaped electrodes constructed according to ${ }^{16}$ were firstly prepared with the membranes previously described and comparative evaluation was performed. The constructed electrodes were soaked in $0.01 \mathrm{~mol} \mathrm{~L}^{-1}$ potassium gibberellate solution before use.

Tubular detectors were developed afterwards ${ }^{15}$ using the membrane composition, which presented the best characteristics observed with the conventional electrodes tested. In this case, the resulting tubular electrodes were conditioned after incorporation in the system and flowing through the above mentioned solution.

\section{Sequential injection system}

Firstly, HC and conveyance paths between RV and the detection system were filled with carrier solution by selecting port 8 and positioning the peristaltic pump (PP) in the propulsion mode. This configuration was kept until the achievement of a stable baseline. The assessment of the tubular electrode behaviour as well as real sample analysis was performed by aspirating solutions $(570 \mu \mathrm{L}$ for 20 seconds) from the first port of RV into the holding coil (HC) of the sequential injection manifold. Then the direction of the carrier stream was reversed and a sample 
zone was propelled towards the detector for 35 seconds at a $2 \mathrm{~mL} \min ^{-1}$ flow-rate.

\section{Results and Discussion}

\section{Evaluation of conventionally shaped electrodes characteristics}

In order to select the sensing membrane which present better working characteristics for flow determination of gibberellate, conventionally shaped electrodes supporting different types of sensing membranes were constructed and evaluated. As the dibutylphthalate properties of ionselective electrodes are strongly influenced by the type of ionic sites present neutral, anionic and cationic charged lipophilic species were considered in the membrane preparation. Ionophore concentration influences the detection limit of the sensors constructed. In a previous work $^{7}$ different concentration ranges of $\mathrm{Mn}(\mathrm{III}) \mathrm{TPP}-\mathrm{Cl}$, namely 1,3 and $6 \mathrm{wt} \%$, were tested in membranes without any additive. Therefore, membranes prepared with $6 \mathrm{wt} \%$ of electroactive material provided electrodes with better characteristics, relatively to the others. They presented higher sensitivity (lower values of LLLR), an increase of the slope of about 10 and $18 \%$ relatively to membranes containing 3 and $1 \mathrm{wt} \%$ of ionophore, respectively, and higher lifetime. Hence, in this work, all potentiometric units were constructed using $6 \mathrm{wt} \%$ of electro active material.

With this purpose, membranes incorporating $6 \mathrm{wt} \%$ of Mn(III)TPP-Cl, $66 \mathrm{wt} \%$ of DBP, $27 \mathrm{wt} \%$ of PVC and $1 \mathrm{wt} \%$ of additive, p-tert-octylphenol (Type 1), sodium tetraphenylborate (Type 2) and tetra-octylammoniumbromide (Type 3) respectively were prepared. For comparison purposes a membrane without incorporating any additive (Type 4) was also prepared. The response characteristics of the electrodes were evaluated (Table 1), by carrying out repetitive calibrations using standard solutions of potassium gibberellate, prepared in MES buffer, in the $10^{-5}$ and $10^{-2}$ mol L $\mathrm{L}^{-1}$ concentration interval. As previously stated the presence of ionic sites in the membranes produce some changes in the calibration parameters once in each case slope, lower limit of linear response (LLLR) or practical detection limit (PDL) values differ from those obtained for the electrode without additive (Type 4). The incorporation of sodium tetraphenylborate into the membrane (Type 2) is beneficial for electrode characteristics once a better LLLR (about $10^{-4} \mathrm{~mol} \mathrm{~L}^{-1}$ ) and PDL (about $5 \times 10^{-5} \mathrm{~mol} \mathrm{~L}^{-1}$ ) values were obtained when compared with the remaining types of electrodes. Except for the Type 3 all the electrodes presented slopes slightly super-Nernstian. This behaviour was previously studied ${ }^{17}$ and it is related to ionophore partial dimerization via hydroxide ion bridges indicating the occurrence of a spontaneous equilibrium of the two forms (monomers and dimers) in the membrane phase when a strong axial ligand is absent. In the presence of the carboxylic group of gibberellate as anion ligand, dimers are broken into monomeric species yielding an equilibrium change in the free ion activities of hydroxide and gibberellate within the membrane phase. Moreover, it could be observed that the presence of additive could influence the extent of dimerization once the slope increased for Type 1 and Type 2 electrodes. The addition of cationic sites to the membrane decreases slope and potential reproducibility evidencing a neutral-based response mechanism of the ionophore. In fact the incorporation of this additive induces a co-ion interference and thus a tendency towards a cationic response evidenced by a substantial decrease of slope and an increase in the LLLR and PDL values.

The influence of $\mathrm{pH}$ on the potential values of electrodes was evaluated for $0.01 \mathrm{~mol} \mathrm{~L}^{-1}$ solutions of gibberellate anion (Table 1). The $\mathrm{pH}$ was changed by adding gibberellic acid solution of equal concentration or concentrated potassium hydroxide solution. As stated in Table 1 the operational $\mathrm{pH}$ range was similar for Type 2 (4.0-8.5) and Type 4 (4.2-8.5) electrodes and a decrease on this parameter was registered for the electrodes incorporating $p$-tert-octylphenol (Type 1) in the membrane (4.55.5). This behaviour results from a higher interference of hydroxide anion as a consequence of the presence of the phenolate anion resulting from p-tert-octylphenol in the membrane of these electrodes ${ }^{18}$ For Type 3 electrodes a

Table 1. General functioning characteristics of ISE sensitive to gibberellate anion

\begin{tabular}{|c|c|c|c|c|c|c|}
\hline $\begin{array}{l}\text { Electrode } \\
\text { Type }\end{array}$ & $\begin{array}{c}\text { Slope } \\
(\mathrm{mV} / \mathrm{dec})\end{array}$ & $\begin{array}{c}\text { LLLR } \\
\left(\mathrm{mol} \mathrm{L}^{-1}\right)\end{array}$ & $\begin{array}{c}\text { PDL } \\
\left(\mathrm{mol} \mathrm{L}^{-1}\right)\end{array}$ & pH Range & $\begin{array}{l}\text { Reproducibility } \\
\left(\mathrm{mV} \cdot \text { day }^{-1}\right)\end{array}$ & $\begin{array}{l}\text { Life time } \\
\text { (months) }\end{array}$ \\
\hline 1 & $-63.1 \pm 0.9$ & $4.0 \times 10^{-4}$ & $1.0 \times 10^{-4}$ & $4.5-5.5$ & \pm 1.9 & $>7$ \\
\hline 2 & $-61.3 \pm 0.4$ & $1.0 \times 10^{-4}$ & $5.0 \times 10^{-5}$ & $4.0-8.5$ & \pm 0.3 & $>8$ \\
\hline 3 & $-45.3 \pm 1.4$ & $5.0 \times 10^{-4}$ & $3.0 \times 10^{-4}$ & $5.0-8.5$ & \pm 3.0 & $\mathrm{a}$ \\
\hline 4 & $-60.0 \pm 0.8$ & $2.0 \times 10^{-4}$ & $1.0 \times 10^{-4}$ & $4.2-8.5$ & \pm 0.5 & $>8$ \\
\hline TE & $-64.5 \pm 1.6$ & $5.0 \times 10^{-4}$ & $3.0 \times 10^{-4}$ & $\mathrm{a}$ & \pm 0.5 & $>5$ \\
\hline
\end{tabular}

a Non-evaluated parameter; TE - Tubular electrode. 
Table 2. Selectivity coefficients of gibberellate electrodes

\begin{tabular}{lcccrrr}
\hline Interferent & $\begin{array}{c}\text { Concentration } \\
\left(\mathrm{mol} \mathrm{L} \mathrm{L}^{-1}\right.\end{array}$ & Type 1 & Type 2 & Type 3 & Type 4 & TE \\
\hline Sulphate & $2 \times 10^{-3}$ & $-0.89 \pm 0.03$ & $-1.11 \pm 0.03$ & $-0.31 \pm 0.03$ & $-1.20 \pm 0.02$ & $-0.85 \pm 0.06$ \\
& $5 \times 10^{-3}$ & $-1.18 \pm 0.01$ & $-1.51 \pm 0.03$ & $-0.58 \pm 0.04$ & $-1.56 \pm 0.02$ & $-1.23 \pm 0.03$ \\
Chloride & $2 \times 10^{-3}$ & $0.36 \pm 0.01$ & $0.31 \pm 0.04$ & $0.44 \pm 0.03$ & $0.40 \pm 0.02$ & $-0.03 \pm 0.05$ \\
& $5 \times 10^{-3}$ & $0.29 \pm 0.02$ & $0.27 \pm 0.04$ & $0.33 \pm 0.02$ & $0.37 \pm 0.02$ & $-0.27 \pm 0.04$ \\
Nitrate & $2 \times 10^{-3}$ & $0.44 \pm 0.01$ & $0.19 \pm 0.02$ & $2.57 \pm 0.04$ & $0.47 \pm 0.05$ & $0.31 \pm 0.06$ \\
& $5 \times 10^{-3}$ & $0.38 \pm 0.02$ & $0.10 \pm 0.02$ & $2.63 \pm 0.02$ & $0.38 \pm 0.03$ & $0.19 \pm 0.07$ \\
Nitrite & $2 \times 10^{-3}$ & $0.67 \pm 0.03$ & $0.70 \pm 0.02$ & $1.35 \pm 0.05$ & $0.79 \pm 0.02$ & $0.51 \pm 0.05$ \\
& $5 \times 10^{-3}$ & $0.63 \pm 0.01$ & $0.65 \pm 0.02$ & $1.40 \pm 0.05$ & $0.73 \pm 0.01$ & $0.37 \pm 0.03$ \\
Bicarbonate & $2 \times 10^{-3}$ & - & $-0.79 \pm 0.05$ & $-0.04 \pm 0.04$ & $-0.88 \pm 0.01$ & $-0.65 \pm 0.06$ \\
& $5 \times 10^{-3}$ & & $-0.92 \pm 0.07$ & $-0.13 \pm 0.03$ & $-1.19 \pm 0.02$ & $-0.81 \pm 0.04$ \\
\hline
\end{tabular}

decrease in the operational $\mathrm{pH}$ range (Table 1) is observed which limits its analytical application.

Interference caused by some common inorganic anions was evaluated by carrying out the determination of the selectivity potentiometric coefficients $\left(\log K^{\mathrm{pot}}\right)$ for chloride, nitrite, nitrate, sulphate and bicarbonate ions by the separated solution method ${ }^{19}$ for interfering concentrations of $2 \times 10^{-3} \mathrm{~mol} \mathrm{~L}^{-1}$ and $5 \times 10^{-3} \mathrm{~mol} \mathrm{~L}^{-1}$, respectively (Table 2). Salicylate and thiocyanate were not tested since they are absent from the gibberellate samples tested.

Electrodes prepared without additive (Type 4), with p-tert-octylphenol (Type 1) or tetraphenylborate (Type 2) are slightly more selective then those that used quaternary ammonium salt (Type 3) as additive, mainly to chloride, nitrate and nitrite. For the latter unit, besides an increase of the extension of interference it was also observed a reversion of the selectivity, resulting in a sequence similar to the Hofmeister pattern. It is well known that an anionselectivity sequence based on a preference towards lipophilic anions is characteristic of membranes based on classical anion exchangers, such as quaternary ammonium salts. ${ }^{9}$ In Type 3 electrodes, the presence of cationic sites induces an anionic response for more lipophilic anions, such as nitrate and the mechanism based on the coordination of the central metal of the porphyrin ring with the analyte is disfavored.

When compared to other units previously described ${ }^{7}$ containing $\mathrm{Mn}$ (III)TPP-Cl. $7 \mathrm{H}_{2} \mathrm{O}$, Type 4 electrodes presented improved general working characteristics namely LLLR, PDL, and specially reproducibility, operational $\mathrm{pH}$ range and life time and extension of interference towards all studied interferents.

\section{Tubular electrodes behaviour in SIA}

As characteristic of continuous flow methodologies, the injection of reduced volumes of sample, in a liquid flow stream, determines its physical dispersion leading to a transient analytical signal in the detector, of reduced intensity when compared with that obtained by conventional analysis. ${ }^{20}$ Furthermore, the reproducibility of measurements depends on the constancy of the hydrodynamic variables of the system, verified periodically in a direct form or by carrying out calibration procedures. To accomplish the determination of gibberellate under flow conditions a tubular electrode (TE) was constructed considering the best characteristics of Type 2 membranes. This tubular electrode was then coupled to a conventional sequential injection system and evaluated using $0.01 \mathrm{~mol}$ $\mathrm{L}^{-1}$ MES buffer solution $\mathrm{pH} 4.3$ as carrier solution.

Some flow parameters were optimised before gibberellate tubular detector evaluation and application. After setting the flow rate at $3.9 \mathrm{~mL} \mathrm{~min}^{-1}$, the injection volume was studied on the range of $140 \mu \mathrm{L}$ to $860 \mu \mathrm{L}$ and a volume corresponding to $570 \mu \mathrm{L}$ was chosen insofar as it corresponded to the minimum injection volume, which enabled maximum analytical signal intensity. The use of lower flow rates leads to a decrease in the sampling rate. Signals with the same intensity but with less reproducibility were equally achieved using higher flow-rates (up to $7.9 \mathrm{~mL} \mathrm{~min}^{-1}$ ), but at the expense of higher injection volumes. A $2.0 \mathrm{~mL} \mathrm{~min}^{-1}$ flow rate was then selected. Using this flow conditions the general working characteristics of the electrodes were assessed by making calibration curves on the range between $5 \times 10^{-5} \mathrm{~mol} \mathrm{~L}^{-1}$ and $10^{-2} \mathrm{~mol} \mathrm{~L}^{-1}$ (Table 1). A slightly increase on slope values $(-64.5 \mathrm{mV} / \mathrm{dec})$ was observed when compared to the corresponding conventionally shaped electrodes (Type 2) as well as an increase on the PDL $\left(3 \times 10^{-4} \mathrm{~mol} \mathrm{~L}^{-1}\right)$ and LLLR $\left(5 \times 10^{-4} \mathrm{~mol} \mathrm{~L}^{-1}\right)$ values (Table 1 and Figure 2).

The determination of potentiometric selectivity coefficients was performed by the separated solutions method ${ }^{19}$ by injections of solutions with the same concentration of main and interfering ion, as used for the conventional electrodes interference evaluation. The results obtained (Table 2) revealed that a general 


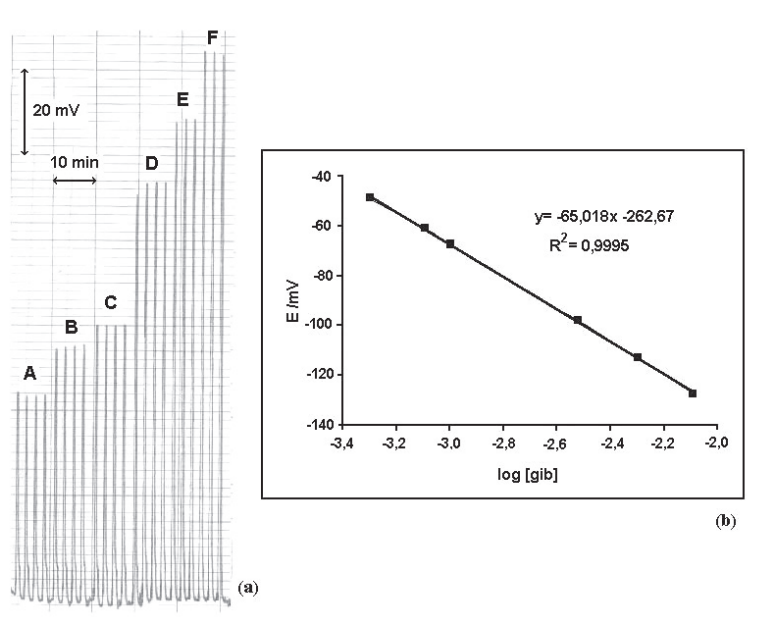

Figure 2. A SIA record obtained with the tubular unit for different standard gibberellate solutions: $(A)=5 \times 10^{-4} \mathrm{~mol} \mathrm{~L}^{-1} ;(B)=8 \times 10^{-4}$ mol L-1; $(\mathrm{C})=1 \times 10^{-3} \mathrm{~mol} \mathrm{~L}^{-1} ;(\mathrm{D})=3 \times 10^{-3} \mathrm{~mol} \mathrm{~L}^{-1} ;(\mathrm{E})=5 \times 10^{-3} \mathrm{~mol} \mathrm{~L}^{-1}$; $(\mathrm{F})=8 \times 10^{-3} \mathrm{~mol} \mathrm{~L}^{-1}$ (a) and respective calibration curve (b).

improvement of selectivity towards the different interferents was obtained except for bicarbonate ion.

In comparison to batch procedures, SIA presents several advantages (Table 3). Sampling rate is 7 times higher and sample and reagents consumption is smaller than in batch, therefore waste production is significantly smaller. Reproducibility of measurements is also better as well as selectivity towards $\mathrm{NO}_{3}^{-}$and $\mathrm{NO}_{2}^{-}$.

Table 3. Comparison of analytical and system characteristics of gibberellate selective electrodes in SIA and batch analysis

\begin{tabular}{lll}
\hline & SIA & Batch $^{\mathrm{a}}$ \\
\hline Slope $(\mathrm{mV} / \mathrm{dec})$ & $-64.5 \pm 1.6$ & $-68.7 \pm 1.8$ \\
LLLR $\left.(\mathrm{mol} \mathrm{L})^{-1}\right)$ & $5 \times 10^{-4}$ & $1 \times 10^{-4}$ \\
PDL (mol L & $3 \times 10^{-4}$ & $5 \times 10^{-5}$ \\
Reproducibility (mV/day) & \pm 0.5 & \pm 1.1 \\
Sampling rate (samples/h) & 30 & 4 \\
Stabilization of electrode response (s) & 10 & 30 \\
Sample volume/analysis $(\mu \mathrm{L})$ & 570 & 20000 \\
Reagent volume/analysis $(\mathrm{mL})$ & 1320 & 20000 \\
\hline
\end{tabular}

${ }^{\mathrm{a}}$ Obtained with electrode type D of reference 7 .

\section{Analytical applications}

To evaluate the analytical usefulness of the sequential injection system with potentiometric detection analysis of commercial formulations containing gibberellic acid was carried out. Table 4 indicates the average of 4 results obtained by SIA with the tubular detector (TE), the analysis of the same samples through direct potentiometry in batch conditions with the previously described electrode ${ }^{7}$ and with an independent method based on the HPLC technique. ${ }^{2}$ As can be observed the proposed procedure gave results with lower relative errors $(<0.5 \%)$ relatively to those provided by conventional units $(<3.3 \%)$ when both are compared with the HPLC method. The improvement of the analytical results is more significant when the complexity of sample increases, such as the case of Berelex formulation.

\section{Conclusions}

The study undertaken shows that with the incorporation of sodium tetraphenylborate as lipophilic anion additive for gibberellate potentiometric membrane preparation enables electrodes with improved characteristics compared to a membrane without additive. This improvement is associated with the increase of linear response range, better selectivity, operational $\mathrm{pH}$ range, reproducibility and lifetime.

The sensor membrane with improved characteristics revealed adequate for the preparation of tubular electrodes for continuous flow determination, thus enabling the development of an automated procedure for gibberellate monitoring at lower costs compared to alternative determination methods previously reported.

\section{Acknowledgements}

One of us (Emília Santos) thanks the FCT (Fundação para a Ciência e Tecnologia) for a PhD Grant (SFRH/BD/ 1435/2000).

Table 4. Determination of gibberellic acid in commercial formulas. Values compared with those obtained by the independent method based on the HPLC technique

\begin{tabular}{|c|c|c|c|c|c|}
\hline Product & $\begin{array}{l}\text { MnTPP-Cl SIA } \\
\text { Determination }\end{array}$ & $\begin{array}{l}\text { MnTPP-Cl Batch } \\
\text { Determination } \\
\text { Ref. } 7\end{array}$ & HPLC method & $\begin{array}{c}\text { Relative error } \\
\text { SIA Determination } \\
(\%)\end{array}$ & $\begin{array}{c}\text { Relative error } \\
\text { Batch Determination } \\
\text { Ref. } 7(\%)\end{array}$ \\
\hline $\begin{array}{l}{ }^{\circ} \text { Ácido Giberélico } \\
1,6 \%(\mathrm{~g} / 100 \mathrm{~mL})\end{array}$ & $1.59 \pm 0.01^{\mathrm{a}}$ & $1.59 \pm 0.04^{\mathrm{a}}$ & $1.59 \pm 0.01^{\mathrm{a}}$ & 0.0 & 0.0 \\
\hline${ }^{\mathrm{c} B e r e l e x}$ (g/100mg) & $11.4 \pm 0.4^{\mathrm{a}}$ & $11.1 \pm 0.2^{\mathrm{a}}$ & $11.48 \pm 0.02^{\mathrm{a}}$ & -0.5 & -3.3 \\
\hline
\end{tabular}

${ }^{a}$ Average $(\mathrm{wt} \%) \pm$ standard deviation $\mathrm{n}=4$; ${ }^{\mathrm{b}}$ Composition: Gibberellic acid $1.6 \mathrm{wt} \%$ in propanol; ${ }^{\mathrm{c}}$ Composition: Gibberellic acid 9 wt $\%$, Gibberellins $1 \mathrm{wt} \%$ and bicarbonate $90 \mathrm{wt} \%$. 


\section{References}

1. Anderson, S.J.; Jarrell, W.M.; Commun. Soil Sci. Plant. Anal. 1988, 19, 617.

2. Castillo, G.; Martinez, S.J.; Chromatrogr. 1997, 782, 137.

3. Rotunno, T.; Argenti, L.; Di-Caterina, R.; Ital. J. Food Sci. 1999, 11, 131.

4. Kumar, P.K.R.; Lonsane, B.K.; J. Chromatogr. 1986, 369 , 222.

5. Blanco, C. C.; Sanchez, G. F. ; J. Assoc. Anal. Chem. 1986, 69, 105.

6. Weiler, E. W.; Weiczorek, U.; Planta 1981, 152, 159.

7. Santos, E.M.G.; Couto, C.M.C.M.; Montenegro, M.C.B.S.M.; Neves, M.G.P.M.S.; Rebelo, S.L.H.; Cavaleiro, J.A.S.; Reis, B. F.; Anal. Bioanal. Chem. 2003, 375, 511.

8. Hofmeister, F.; Arch.Exp.Pathol. Pharmakol. 1888, 24, 247.

9. Bühlmann, P.; Pretsch, E.; Bakker, E.; Chem. Rev. 1988, 98, 1593.

10. Hutchins, R.S.; Bachas, L. G.; Anal. Chem. 1995, 67, 1654.

11. Chaniotakis, N.A.; Chasser, A.M.; Meyerhoff, M.E.; Groves, J.T.; Anal. Chem 1988, 60, 185.

12. Bakker E., Malinowska E., Schiller R.D., Meyerhoff M.E. ; Talanta 1994, 41, 881 .
13. Amemiya, S.; Bühlmann, P.; Pretsch, E.; Rusterhoiz, B.; Umezawa, Y.; Anal. Chem. 2000, 72, 1618.

14. Alegret, S.; Alonso, J.; Bártoli, J.; Paulís, J.M.; Lima, J.L.F.C.; Machado, A.A.S.C.; Anal. Chim. Acta 1984, 164, 147.

15. Lima, J.L.F.C.; Montenegro, M.C.B.S.M.; Roque da Silva, A.M.; J. Flow Injection Anal. 1990, 7, 19.

16. Lima, J.L.F.C.; Montenegro, M.C.B.S.M.; Roque da Silva, A.M.; J. Pharm. Biomed. Anal. 1990, 8, 701.

17. Steinle, E. D.; Amemiya, S.; Bühlmann, P.; Meyerhoff, M. E.; Anal. Chem. 2000, 72, 5766.

18. Hara, H.; Kondoh, Y.; Mitani, O.; Okazaki, S.; Anal. Chem. 1990, 62, 1139.

19. IUPAC, Analytical Chemistry Division Commission on Analytical Nomenclature; Pure Appl Chem 1981, 53,1907

20. Ruzicka, J.; Marshall, G.D.; Anal. Chim. Acta 1990, 237, 329.

Received: July 17, 2003

Published on the web: September 9, 2004

FAPESP helped in meeting the publication costs of this article. 